YANCHUK, A. (1996): General and specific combining ability from disconnected partial diallels of coastal Douglas-fir. Silvae Genet. 45: 37-45.

YE, T. Z. and K. J. S. JAYAWICKRAMA (2008): Efficiency of using spatial analysis in firest-generation coastal Douglas-fir progeny tests in the US Pacific Northwest. Tree Genetics and Genomes 4: 677-692.
ZAS, R. (2006): Iterative kriging for removing spatial autocorrelation in analysis of forest genetic trials. Tree Genetics and Genomes 2: 177-185.

Zhelev, P., I. Ekberg, G. Eriksson and L. Norell (2003): Genotype environment interactions in four full-sib progeny trials of Pinus sylvestris (L.) with varying site indices. Forest Genetics 10: 93-102.

\title{
Near rotation-length performance of selected hybrid larch in Central Maine, U.S.A.
}

\author{
By M. S. Greenwood ${ }^{1)}$, B. E. Roth ${ }^{\left.1,{ }^{*}\right)}$, D. MAASs $^{2)}$ and L. C. IRLAND ${ }^{1)}$
}

(Received $7^{\text {th }}$ May 2015)

\begin{abstract}
Twenty-two year measurements of a test of inter- and intraspecific larch hybrids among European (E), Japanese (J) and tamarack (T) parents growing in central Maine reveal significant hybrid vigor, especially among crosses involving $J$ and $\mathrm{E}$ parents. The mean heights and diameters of all the interspecific crosses between $\mathrm{J}$ and $\mathrm{E}$ parents exceeded those of intraspecific crosses among either of the parents. The mean height after 22 years for all 17 $\mathrm{JxE}$ and ExJ crosses was $19.2 \mathrm{~m}$ (63 feet), which compares favorably with heights of loblolly pine plantations at age 25 growing in the southeastern USA, where site index ranged from $12.2 \mathrm{~m}$ to $24.4 \mathrm{~m}$ (40 and 80 feet respectively). In addition the mean height of these larch crosses was $30 \%$ greater than that of a control hybrid seed lot of German origin. Crosses between $\mathrm{E}$ and $\mathrm{T}$ parents also performed well, but exhibited relatively poor form, and seed set was very low. Seed set and viability for crosses between $\mathrm{J}$ and $\mathrm{E}$ were as good as

1) School of Forest Resources, University of Maine, 5755 Nutting Hall, Orono ME 04469-5755, USA.

2) 5 Wildwood Circle, Portland, ME 04103, USA.

*) Corresponding author: BRIAN E. ROTH.

Phone (207) 581-2861. E-Mail: brian.roth@maine.edu
\end{abstract}

intraspecific parental crosses. Therefore propagation of hybrid larch crosses via controlled pollination and rooted cuttings is feasible, and the potential benefits of larch plantations for Maine's forest economy are briefly discussed.

Key Words: Hybrid larch, hybrid vigor, heterobeltiosis, Japanese larch, European larch, tamarack

\section{Introduction}

Reports of naturally occurring larch hybrids between European (Larix decidua Mill.) and Japanese larch (L. kaempferi (Lamb) Carriere) exhibiting exceptional growth followed the introduction of Japanese larch into European arboretums in 1861 (SANDER and LAANELAID, 2007). Since then, there has been considerable interest in realizing the potential of larch hybrids in France, Sweden, Quebec, the People's Republic of China and throughout US as a rapidly growing plantation species (PÂQUES, 1989; Perron, 2008; Eco et al., 2004). Over the last 30 years, plantations of an open-pollinated half-sib $\mathrm{E} \times \mathrm{J}$ family from a German seed orchard (LANGNER and SCHNECK, 1998) have been established in Maine, Nova Scotia, the Lake States and the state of Oregon. In Maine 
over 10,000 acres of the hybrid were planted, in part to fill the gap in the wood supply following the spruce budworm outbreak in the 1970's and 80 's and also as a hedge against another spruce budworm epidemic ${ }^{3)}$. In the Lake States about 100,000 trees per year of the hybrid are being planted, in Nova Scotia about 125 acres per year, and its resistance to the Swiss Needle Cast fungus makes it a desirable replacement for Douglas fir on susceptible sites in Oregon ${ }^{4}$. In Quebec there has been increased demand for the hybrid and a breeding program to produce further genetic improvement is underway (PERRON, 2008).

In Maine, intensive forest management practices including plantation establishment have declined over the last 25 years due to a divestiture of timberlands by integrated wood products companies caused by changes in tax laws and globalization of markets (KELLISON, 2014). In Maine, this has resulted in a drastic shift from industrial forest land ownership to corporate investors with little interest in long-term investment in silviculture. In addition, exaggerated past projections about the demand for soft wood fiber (e.g. EINSPAHR et al., 1984) were confounded by dramatic increases in the proportion hardwood used in pulp, as well as decreased demand for paper due to the replacement of print media with electronic media. Nonetheless the volume of timber harvested in Maine is not declining (Maine Forest Service ACtivities REPORT, 2014) and there is no reason to expect that the demand for good quality structural lumber will decline in the future. Also, given that spruce budworm outbreaks are increasing in Eastern Canada and Northern Maine, there are justifications for establishment of plantations of fast-growing species that may also be resistant to the spruce budworm ${ }^{3}$.

In Maine, recent measurements of a 27 yearold species trial, which included hybrid larch, revealed that the hybrid of German origin was growing at a rate of about $12 \mathrm{~m}^{3} / \mathrm{ha} / \mathrm{y}$ and produced $35 \%$ more total volume than the next best species (red pine). $86 \%$ of this volume was of potential sawlog size (unpublished data,

\footnotetext{
3) There is some anecdotal evidence that the spruce budworm had little impact on Eastern larch (Larix laricina (duRoi)K. Koch) during the last budworm outbreak, but its effects on hybrid larch are at present unknown.

$\left.{ }^{4}\right)$ Personal communication 2015 by Carl Haag, Larix consulting, 274 S. Reynolds Road, Winslow, ME 04901 USA.
}

2014). A potential rotation age that is less than half that of natural stands (which is 50 to 70 years for natural stands in Maine) could be realized with hybrid larch. In addition, partial harvesting has increased dramatically since 1989 , and in order to maintain a constant wood supply, the area harvested in Maine has nearly doubled. The increased harvest footprint is due to the fact that the volume of wood harvested per acre has decreased by about half since 1989 (Maine Forest Service Silvicultural ActiviTIES REPORTS, 2014).

Therefore we explored the possibility of realizing even greater growth gains from interspecific full-sib hybrid families by selecting parents with good growth and form from locally grown plantations. A test including crosses among three larch species was established in 1992 (BALTUNIS et al., 1998). Our breeding design closely resembled one recently proposed by PERRON (2008) in order to demonstrate hybrid vigor among full-sib families of hybrids between $\mathrm{J}$ and $\mathrm{E}$ parents (L. x marschlinsii Coaz) in Quebec. Perron proposed a complete diallel between $6 \mathrm{~J}$ and $6 \mathrm{E}$ parents, which included reciprocal crosses between $\mathrm{J}$ and $\mathrm{E}$ parents. Here we report the results of measurements of a 22 year-old progeny test consisting of full-sib intra- and interspecific hybrids among tamarack (Larix laricina, (du Roi) K. Koch)), Japanese and European larch.

This report describes:

1. Hybrid vigor exhibited by interspecific hybrids among 3 larch species. Hybrid vigor can occur as heterosis (when the hybrid mean for a given trait exceeds the combined mean of both parents) or heterobeltiosis (when the hybrid mean exceeds the mean of the best parent).

2. Stability of family performance over time.

3 . The advantages and feasibility of mass producing and planting hybrids.

\section{Materials and Methods}

\section{Plant material, test design}

An indoor demonstration breeding orchard consisting of six parents each of $J$ (Japanese larch, six clones), E (European larch, 5 clones) and T (Tamarack or Eastern larch, six clones), all selected for good growth and form, was established in 1987 in order to create interspecific and intraspecific crosses among all three 
species. Each cross is identified by 2 letters, the first indicating the species of the female parent, the second the male parent, followed by two numbers, the first representing the female clone, the second the male clone. For clonal origins of the clones for each species, see BALTUNIS et al., 1998. The E parents were selected from Polish provenances planted in 28-37 year-old tests in Iowa and New Hampshire, while J parents were cloned from provenances that exhibited superior growth in 10 year-old tests located in Maine (EYsTEINSSON et al., 1993).

$\mathrm{E}$ and $\mathrm{J}$ hybridized readily, and as female parents produced similar numbers of seed per cone (89 and 87 respectively) with seed viabilities of $58 \%$ and $48 \%$ for $\mathrm{E}$ and $\mathrm{J}$ respectively (Eysteinsson, 1992). Seventeen full-sib crosses were available for testing, 9 with $\mathrm{J}$ as female and 8 with $\mathrm{E}$ as female. There were 5 pairs of reciprocal crosses. Seed numbers per cone and seed viability was comparable to the intraspecific crosses for both parents. Seed set for interspecific crosses involving $\mathrm{T}$ was relatively poor, resulting in only $6 \mathrm{~T} \times \mathrm{E}$ crosses with enough seed to be included in the test. Seed set and viability for $\mathrm{E} \times \mathrm{T}$ was extremely poor, so seed from the latter cross were pooled into a single halfsib family. $\mathrm{T} \times \mathrm{J}$ crosses resulted in very low seed viability, while $\mathrm{J} \times \mathrm{T}$ were almost completely unsuccessful. Intraspecific crosses with $\mathrm{J}, \mathrm{E}$ and $\mathrm{T}$ as parents yielded 7, 7 and 9 crosses respectively.

A replicated field test consisting of a total of 51 families, including 7 hybrid groups of interand intraspecific hybrids, plus 3 check lots was established in May 1992 in west central Maine (Figure 1). The 3 check lots consisted of: 1) an open pollinated European larch family (XLD-489), 2) an ExJ hybrid from a single female parent (XLD-LL-7-89, which originated in Germany from a single cloned E parent which was mass pollinated with pollen collected from a nearby Japanese larch provenance trial (LANGNER and SCHNECK, 1998) and 3) a controlled cross of a pollen mix from two male parents on a single $L$. laricina female parent. The test consisted of 10 complete blocks with randomly located 3 tree row plots for each family, and the perimeter of the test was surrounded by a border row of extra trees. Spacing between trees was $2.3 \mathrm{~m}$. For further details on parental origin, breeding and test design, as well as site preparation and release see EYSTEINSSON (1992) and BALTUNIS et al. (1998).

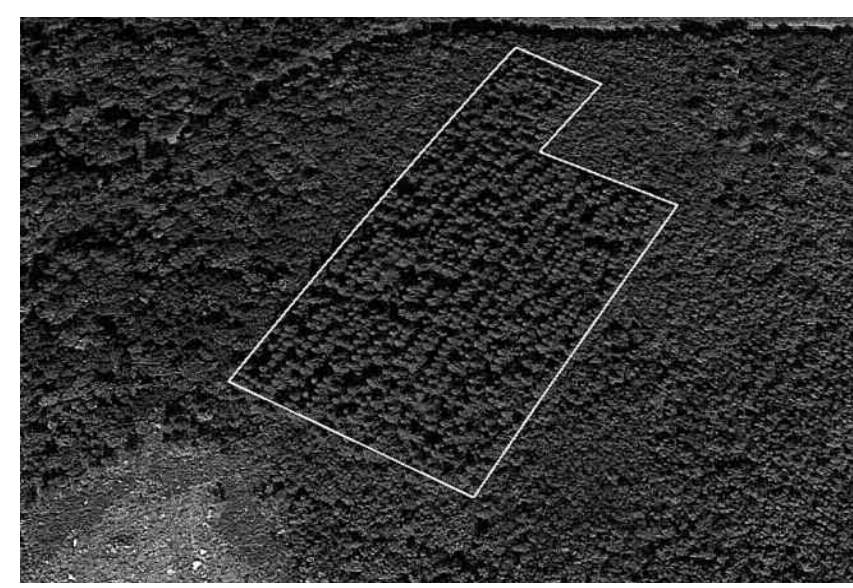

Figure 1. - Aerial photo of the test site taken in 1997. It is located in west-central Maine on an upland site (about $600 \mathrm{~m}$ above sea level) on a drumlinoid ridge underlain by a well-drained deep sandy loam soil. Precipitation ranges from $64-107 \mathrm{~cm}$ and frost-free days from 80-145 days (USDA Natural Resources Conservation Services). There are 10 blocks, each with randomly located 3 tree plots representing each of the 51 families. The whole test is surrounded by a double border row of extra trees.

The test was re-measured after 4,9 and 22 growing seasons. Tree height in 2013 was measured using a Haglöf vertexIV hypsometer, and diameter was measured at $1.37 \mathrm{~m}$ (DBH). Estimates of stem straightness, stem defect, and branch morphology were done within a subset of two blocks due to time constraints, on a scale of 1 to 5 , with 1 being best and 5 worst. Stem defect was defined as stem height to where the main stem broke off or formed a double stem. Branch morphology was rough estimate of branch density and diameter, with 5 indicating a relatively high branch density of large diameter branches. No statistical analysis was done on estimates of stem quality.

\section{Statistical analysis}

Tree volumes were calculated using equations published for larch in LI et al. (2012). Analyses of variance (ANOVA) were performed at the hybrid group (equation 1) and family (equation 2) levels using PROC MIXED in SAS according to:

$$
\text { Eq 1: } \mathrm{Y}_{i j k}=\mu+\mathrm{H}_{i}+\mathrm{B}_{j}+(\mathrm{HB})_{i j}+\mathrm{w}_{i j k}
$$

where $\mathrm{Y}_{i j k}$ is the response variables of $\mathrm{DBH}, \mathrm{HT}$ (height) and VOL (volume) of the $k$ th tree of the $i$ th hybrid group in the $j$ th block $(\mathrm{j}=1,2, \ldots 10$; $\mathrm{i}=1,2, \ldots 7), \mu$ is the overall mean; $\mathrm{H}_{i}$ is the fixed main effect of hybrid group, $\mathrm{B}_{j}$ is the random 
main effect of block, $(\mathrm{HB})_{i j}$ is the their interaction and $\mathrm{w}_{i j k}$ is the random error. Main effect of hybrid group was tested using $(\mathrm{HB})_{i j}$ interaction as the error term. Least squares means were generated for significant variables and separation of means were tested using Bonferroni protected tests at the $5 \%$ level of significance.

Equation 2 was used to test for differences among families:

$$
\text { Eq 2: } \mathrm{Y}_{i j}=\mu+\mathrm{F}_{i}+\mathrm{B}_{j}+\mathrm{w}_{i j}
$$

where $\mathrm{Y}_{i j}$ is the response variables of $\mathrm{DBH}, \mathrm{HT}$ (height) and VOL (volume) of the $k$ th tree of the $i$ th family in the $j$ th block $(\mathrm{j}=1,2, \ldots 10$; $\mathrm{i}=1,2, \ldots 51), \mu$ is the overall mean; $\mathrm{F}_{i}$ is the fixed main effect of family, $\mathrm{B}_{j}$ is the random main effect of block, and $\mathrm{w}_{i j}$ is the random error. Family effect was tested using the $(\mathrm{FB})_{i j}$ interaction as the random error term. Least squares means were generated for significant variables and separation of means were tested using Bonferroni protected tests at the $5 \%$ level of significance.

\section{Results}

\section{Hybrid groups, hybrid vigor}

Means for survival, height, $\mathrm{DBH}$ and stem volume for all hybrid groups are shown in Table 1. Survival across all hybrid groups was $64 \%$, down from 81\% 1 year after planting in 1992 . The best survival among the 7 hybrid groups was exhibited by the EJ and JE crosses (76 and $70 \%$ respectively, down from 83 and $77 \%$ ). Survival of TT, the half-sib check lot, was the worst at $48 \%$, down $43 \%$. Most of the crosses with $\mathrm{T}$ as a parent suffered greater mortality than the test average. Survival of the XLD-4-89 and XLD-LL-89 check lots was 67 and $61 \%$, down 10 and $16 \%$ respectively.

The main effects of 2013 height, DBH and Volume were highly significant among the hybrid groups $(\mathrm{p}<0.0001)$, but they did not significantly interact with block. Mean separation shows that the interspecific hybrid groups means for both JE and EJ crosses are consistently better than the intraspecific hybrids for all three parameters, as is shown in figure 2 and table 1. There was no evidence favoring either $\mathrm{J}$ or $\mathrm{E}$ as female parents despite the larger seed size of Japanese larch $(\mathrm{p}<0.0001)$. Therefore all the JE and EJ crosses showed both heterosis and heterobeltiosis. Heterobeltiosis for the hybrid has been previously reported by FERRAND and BASTIEN (1985).

The ET cross, resulting from a mixture of seed from several parents also performed very well. The XLD-4-89 (European) check lot, resulting from open pollinated European larch in Poland, performed somewhat less well than the full-sib EE crosses made from US grown $L$. decidua parents, but the differences were not statistically significant (Table 1). The performance of the XLD-LL-7-89 hybrid was significantly lower than that of either JE or EJ crosses.

Table 1. - Least Square Means (LSMean) for percent survival, total height, DBH, and individual tree stem volume by hybrid group at age 22. Commercial check means (XLD-4-89 \& XLD-LL-7-89) are listed for comparison. Values within a column followed by the same letter are not significantly different at alpha $=0.05$ using Bonferroni's protected LSD. Numbers in parentheses in the stem volume column represent age 22 rank versus age 5 rank.

\begin{tabular}{|c|c|c|c|c|c|c|c|c|}
\hline & \multicolumn{2}{|c|}{$\begin{array}{c}\text { Survival } \\
(\%)\end{array}$} & \multicolumn{2}{|c|}{$\begin{array}{c}\text { Height } \\
\text { (mi) }\end{array}$} & \multicolumn{2}{|c|}{$\begin{array}{l}\mathrm{DBH} \\
(\mathrm{cm})\end{array}$} & \multicolumn{2}{|c|}{$\begin{array}{c}\text { Stem Volume } \\
\left(\mathrm{dm}^{3}\right)\end{array}$} \\
\hline Hybrid Group & IS Mean & $S E$ & LS Mean & $S E$ & LSS Mean & $S E$ & TSS Mean & $S E$ \\
\hline ET & $72 \mathrm{ab}$ & 8.7 & $20.2 a$ & 0.6 & $25.1 \mathrm{ab}$ & 0.9 & $435.8(1-1) \mathrm{a}$ & 27.9 \\
\hline $\mathrm{JL}$ & $70 \mathrm{ab}$ & 4.1 & $19.2 \mathrm{a}$ & 0.3 & $25.4 a$ & 0.4 & $429.8(2-4) \mathrm{a}$ & 13.1 \\
\hline EJ & $76 a$ & 4.2 & $19.2 \mathrm{a}$ & 0.3 & $25.1 \mathrm{a}$ & 0.4 & $428.7(3-5) a$ & 13.2 \\
\hline $\mathrm{TE}$ & $60 \mathrm{ab}$ & 4.5 & $18.3 \mathrm{ab}$ & 0.4 & $22.2 \mathrm{bc}$ & 0.5 & $322.2(4-3) b$ & 15.3 \\
\hline IE: & $76 a$ & 4.3 & $17.7 \mathrm{~b}$ & 0.3 & $20.7 \mathrm{c}$ & 0.5 & $273.5(5-7) \mathrm{c}$ & 13.7 \\
\hline lJ & $51 \mathrm{~b}$ & 6.7 & $16.4 \mathrm{bc}$ & 0.5 & $19.9 \mathrm{~cd}$ & 0.8 & $263.6(6-2) \mathrm{cd}$ & 25.2 \\
\hline XLD-4-89 & $67 \mathrm{ab}$ & 8.6 & $17 \mathrm{bc}$ & 0.6 & $20.4 \mathrm{~cd}$ & 1.0 & $248.3(7-9) \mathrm{cd}$ & 28.4 \\
\hline XLD-LL-7-89 & $6 l a b$ & 9.1 & $16.4 \mathrm{bc}$ & 0.7 & $18.6 \mathrm{~cd}$ & 1.1 & $231.3(8-10) \mathrm{cd}$ & 31.2 \\
\hline J.J & $58 \mathrm{~b}$ & 4.5 & $15.8 \mathrm{c}$ & 0.4 & $17.7 \mathrm{~d}$ & 0.5 & $182.9(9-8) \mathrm{d}$ & 15.4 \\
\hline T"T & $48 \mathrm{~b}$ & 4.0 & $13.1 \mathrm{~d}$ & 0.4 & $14.2 \mathrm{e}$ & 0.5 & $106.2(10-6) e$ & 14.5 \\
\hline
\end{tabular}




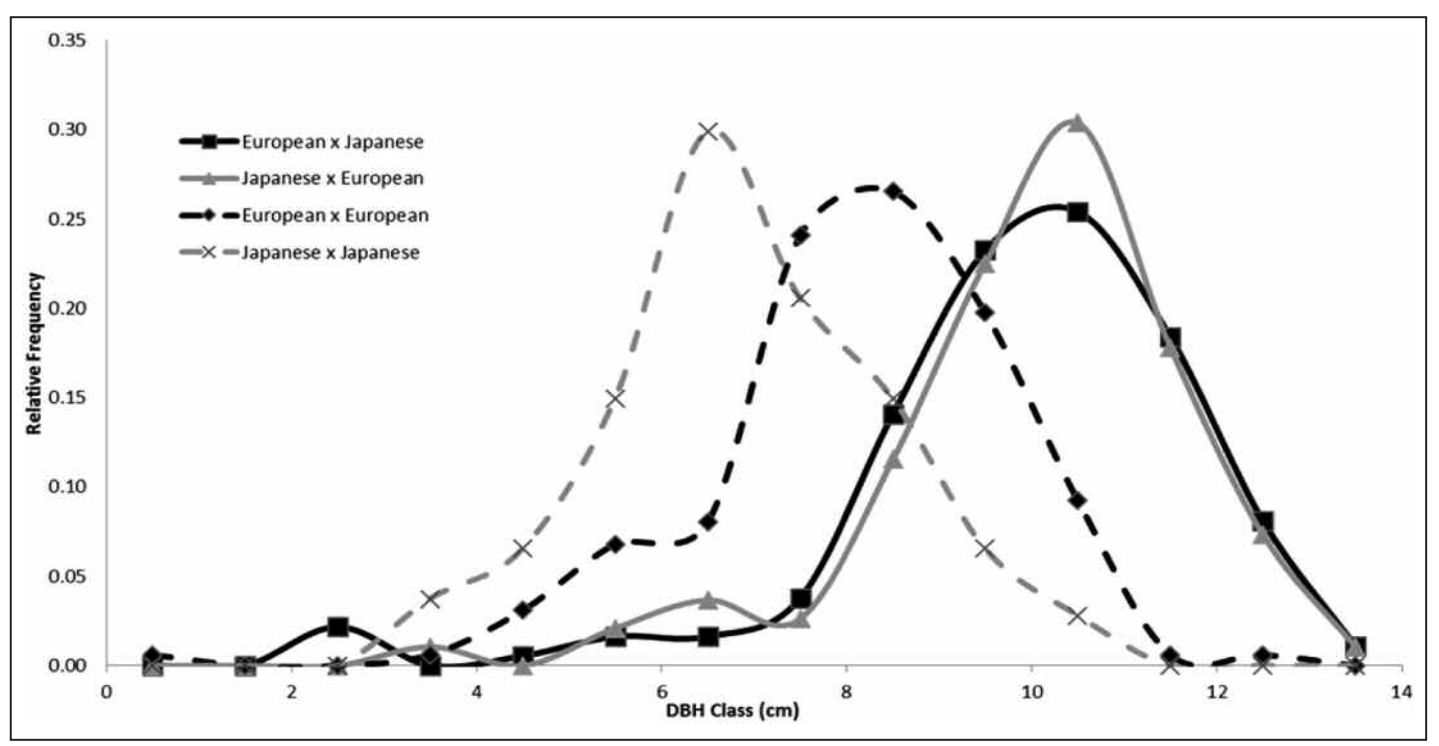

Figure 2. - Relative frequency of trees in one inch $\mathrm{DBH}$ classes for $\mathrm{E} \times \mathrm{J}, \mathrm{J} \times \mathrm{E}, \mathrm{E} \times \mathrm{E}$ and $\mathrm{J} \times \mathbf{J}$ families. The data are normalized for visual effect, so that the area under the curves for each hybrid group is similar in order to compensate for differences in sample size between groups.

Crosses involving $\mathrm{J}$ and $\mathrm{E}$ parents not only exhibited hybrid vigor in terms of growth but also the least defect (in terms of broken or forked tops) of any of the families in the test. Overall the test mean was about $17 \%$, while EJ and JE means were about $5 \%$. Defect for EE and JJ crosses was 15 and $17 \%$ respectively. TT crosses showed the most defect at $54 \%$, while ET and TE crosses showed 13 and $11 \%$ respectively. The check lots XLD-489 and XLD-LL-789 showed 27 and $6 \%$ defect respectively. Estimates of branch morphology and stem straightness were crude and did not show consistent patterns of variation among hybrid groups; crosses with $\mathrm{T}$ as a parent tended to score above the test average, especially TT.

\section{Hybrid group and family rank changes}

Hybrid group rank changes in height from 1994 to 2013 are shown in table 1. While the ET hybrid group rankings did not change much, the JE and EJ groups advanced from $4^{\text {th }}$ to $2^{\text {nd }}$ and $5^{\text {th }}$ to $3^{\text {rd }}$ respectively. The JJ, TJ and TT group ranks declined by four, four and two places respectively. The EE group advanced 2 places and in general all groups with $\mathrm{E}$ as a parent increased in rank, which included the check lots XLD-489 and XLD-LL-7-89.

Full-sib family rank changes for the 17 families involving $\mathrm{J}$ and $\mathrm{E}$ parents are shown in Table 2. The average ranks of these families decreased from 18 to 7 from age 4 to 22 . Some individual families, like JE33, showed dramatic increases in rank. Although there were considerable changes in rank over time, most of the families increased in rank over time; e.g. 15 of the 17 families increased in rank from 1999 to 2013. With the exception of one ET family, 11 of the best families in the test involved $\mathrm{J}$ and $\mathrm{E}$ parents. All the crosses between $J$ and $E$ parents ranked better than any of the intraspecific crosses among either parent, and as a hybrid group decreased in rank more than any of the other groups.

\section{Clonal bias}

Clonal bias favoring the best crosses could include: 1) dominant clonal gender, and 2) dominant clones. Four of the 11 parental clones contributed to the majority of the crosses made; Clones J2, J6, E1 and E3 were parents in all but 1 of the 17 families. Considering only the 17 families shown in table 2 , female parental gender of the top 10 families are evenly divided between Japanese and European larch. Thus there does not seem to be a dominant parental gender. J2 and J6 were parents in 13 of the families, 5 of which were included in the top 8 crosses, while 7 were in the bottom 8 . E1 and E3 were parents in 10 families, 7 in the top 8 and 4 in the bottom 8. Clone E3 was represented in the top 3 families. Although only a 
few clones were involved in most of the crosses, the European clones may be favored in the best families. The intraspecific crosses among $\mathrm{E}$ parents exhibited significantly better height growth than those among J parents (Table 1).

\section{Discussion}

Most reports of hybrid vigor by crosses between $\mathrm{J}$ and $\mathrm{E}$ parents resulted from a small number of crosses involving only one or a few parental sources (PÂQUES 1989, 2004). In addition, tests which compare hybrid performance with that of intraspecific crosses among their parents are rare. Hybrid larch has been identified as the most productive variety in Quebec's commercial forests, and a hybrid breeding strategy is underway (PerRon, 2008). PerRon has proposed a second generation breeding strategy where progeny from intra- and interspecific diallels of selected Japanese and European parents will be evaluated simultaneously.

Our study represents a small scale test of this approach, presenting data from a 22 year-old test containing 7 intraspecific crosses for each set of $\mathrm{J}$ and $\mathrm{E}$ parents and 17 interspecific hybrids between $J$ and $E$. We have demonstrated substantial heterosis and heterobeltiosis for hybrids between $\mathrm{J}$ and $\mathrm{E}$ parents, since all the interspecific hybrid means exceed the means for the best intraspecific parental crosses. There were no apparent differences between reciprocal crosses with either $\mathrm{J}$ or $\mathrm{E}$ as female parent (Table 2). An exception is the control operational $\mathrm{E} \times \mathrm{J}$ hybrid XLD-LL-7-89 of German origin, whose mean was less than that of the $\mathrm{E} \times \mathrm{E}$ crosses (Table 1 ). The superior performance of the hybrids we made is probably because their parents represented locally adapted selections that were chosen on the basis of relatively good height growth. Nonetheless, the control hybrid greatly improved in rank from 50 at year 4 (next to last) to 33 in year 22. Overall, the rank of hybrid families with $\mathrm{J}$ and $\mathrm{E}$ as parents increased over time, with 14 of the 17 families improving in rank over time (Table 2).

In addition we have shown that hybrids between $\mathrm{T} \times \mathrm{E}$ and $\mathrm{T} \times \mathrm{J}$ exhibited hybrid vigor, although seed set for these crosses was relatively low ( $18 \%$ and $1 \%$ respectively). $\mathrm{E} \times \mathrm{T}$ crosses resulted in very low seed viability (about $3 \%$ ), but the pooled mean for height of seedlings from several crosses was the best in the test (Table 1). PÂQUES (1992) was unable to make $\mathrm{T} \times \mathrm{E}$ crosses because $\mathrm{T}$ flowered before $\mathrm{E}$ pollen was available. His attempts at a $\mathrm{T} \times \mathrm{J}$ cross resulted in poor seed set, and the height growth of this hybrid was less than that of either parent. Although our estimates of stem quality were crude and done on only 2 blocks, T parentage was associated with relatively high levels of stem defect, and to a lesser extent with stem straightness and branch morphology. PÂQUES (2004) demonstrated significant parental effects on stem morphology in $\mathrm{J} \times \mathrm{E}$ hybrids.

Table 2. - Height rank changes for the 17 full-sib families with $\mathrm{J}$ and $\mathrm{E}$ parents from 1996 to 2013.

\begin{tabular}{|l|c|c|c|c|}
\hline Family & H of trees & Rank, 22y & Rank, $7 y$ & Rank, 4y \\
\hline EJ31 & 19 & 2 & 25 & 16 \\
\hline JE33 & 13 & 3 & 14 & 38 \\
\hline JE63 & 22 & 4 & 9 & 27 \\
\hline JE21 & 27 & 5 & 12 & 34 \\
\hline IJ42 & 29 & 6 & 2 & 1 \\
\hline EJ46 & 22 & 7 & 11 & 31 \\
\hline EJ11 & 30 & 8 & 1 & 6 \\
\hline EJ36 & 26 & 9 & 17 & 25 \\
\hline JE65 & 16 & 10 & 6 & 14 \\
JE11 & 29 & 11 & 4 & 15 \\
\hline JE64 & 23 & 12 & 5 & 17 \\
\hline EJ16 & 21 & 14 & 26 & 43 \\
\hline JI62 & 21 & 15 & 3 & 26 \\
\hline EJ26 & 24 & 16 & 23 & 29 \\
\hline JE25 & 26 & 17 & 21 & 13 \\
\hline JE23 & 18 & 19 & 15 & 24 \\
EJ12 & 23 & 24 & 28 & 36 \\
\hline
\end{tabular}


Production of hybrids between $\mathrm{J}$ and $\mathrm{E}$ parents for plantation establishment should be considered for several reasons: 1) they exhibit considerable hybrid vigor with growth rates comparable to Southern pine, 2) have very good survival in the field, 3) have good stem form, 4) the crosses can be made with good seed set comparable to that of intraspecific crosses of either parent, and 5) Hybrid larch cuttings root well (PÂQUES, 1992; PEER and GREENWOOD, 2001). PÂQUES (1992) reports that 80 and $62 \%$ of cuttings rooted from 2 year-old seedling donor ortets of $\mathrm{E} \times \mathrm{J}$ and $\mathrm{J} \times \mathrm{E}$ crosses respectively. PeER and Greenwood (2001) found that cuttings from 1-2 year-old ortets rooted $85-100 \%$ of the time. In addition, hybrid larch plantations represent an opportunity to enhance the economic value of timber output and at the same time increase the rate and amount of carbon sequestered in the Maine woods.

The average height at age 22 of all 17 hybrid families with $\mathrm{J}$ and $\mathrm{E}$ parents was $19.1 \mathrm{~m}$ (63 feet). Site index values for loblolly pine plantations at age 25 range from $12.2 \mathrm{~m}$ (40 feet) to $24.4 \mathrm{~m}$ (80 feet), so hybrid larch plantations exhibit growth that is quite comparable to southern pine on average sites (HARRISON and BORDEERS, 1996). In the South, even though loblolly pine plantations are only $11 \%$ of the forested area, they provide $40 \%$ of the total timber volume (CARTER and Foster, 2006). Therefore incentives for limited establishment of hybrid larch plantations could increase the economic value of Maine's forests in this time of uncertain economic and climatic change. The demand for newsprint and coated paper is steadily declining because digital media are replacing magazines and newspapers. This is reflected in a recent wave of mill closures. However the softwood lumber market has excellent prospects as the nation's housing sector slowly rebounds from the worst downturn since the Great Depression. Maine's prospects in softwood lumber are improved by harvest cutbacks in Eastern Canada and the surplus of beetlekilled wood from British Columbia (L.C. Irland, personal communication 2015).

In the current wood products market, the wood properties of larches are competitive with native species. The mechanical properties of JxE larch hybrids rank higher than either of the parents in France (PÂQUES, 1989). Larch wood in general is more dense and stronger than white pine, red spruce or balsam fir (KRETSChMANN, 2010). Japanese, European and Eastern larch all share similar wood properties with Douglas fir, which is considered one of the best domestic sources of dimension lumber because of its high strength, density and rot resistance (Western Wood Products AssociATION, 2002). $\mathrm{J}$ and $\mathrm{E}$ are both moderately rot resistant (CURNEL et al., 2008), and GIERLINGER et al. (2004) report that the $J$ parent confers greater rot resistance to the $\mathrm{E} \times \mathrm{J}$ hybrids than the E parent.

Also larch plantations can potentially alleviate the estimated social cost of carbon, which has increased almost 5 fold since 2008 (PIZER et al., 2014). Hybrid larch with its rapid growth and relatively dense wood can sequester carbon faster than any other northeastern conifer. Measures to alleviate the effects of atmospheric carbon dioxide will become more urgent as the climate continues to warm. Hybrid larch presents the state of Maine with an opportunity to proactively address this issue.

\section{Conclusions}

1. Crosses between J and E parents outperform either of their parents (heterobeltiosis), and the locally produced hybrids described in this paper were more than $30 \%$ taller than the XLD-LL-89 hybrid check lot (LANGNER and ScHNECK, 1998) that has been extensively planted in Maine and elsewhere with excellent results.

2. Family rankings were unstable, but hybrids between $J$ and $E$ parents improved steadily in rank over time.

3. Hybrid families from $\mathrm{J}$ and $\mathrm{E}$ parents set seed as well as their parents and hybrid families can be multiplied via vegetative propagation.

This study demonstrates that high potential exists for introduction of these hybrids into commercial forestry practice in the north and central US. Growth performance substantially exceeds that for species now being planted. We are preparing a further comparison and economic analysis of hybrid performance relative to other species. We predict that by the time new plantations of hybrids are harvested, markets for larches as solid wood products, pulpwood, and biomass energy will exist. 


\section{Acknowledgements}

Support of the Cooperative Forestry Research Unit of the University of Maine is gratefully acknowledged. We are also grateful to CARL HAAG for providing the site for this study and for his helpful discussion while preparing this paper. AARON WEISKITTEL provided valuable advice on volume estimates as well as useful comments on the manuscript.

\section{References}

Baltunis, B. S., M. S. Greenwood and T. EysteinsSON (1998): Hybrid vigor in Larix: growth of intraand interspecific hybrids of Larix decidua, L. laricina, and L. kaempferi after 5 years. Silvae Genetica 47: 288-293.

Carter, M. C. and C. D. Foster (2006): Milestones and millstones: A retrospective on 50 years of research to improve productivity of loblolly pine plantations. Forest Ecology and Management 227: 137-144.

Curnel, Y., D. Jaques, N. Gerlinger and L. PÂques (2008): Variation in the decay resistance of larch to fungi. Annals of Forest Science 65: 810-818.

Eco, M. E., M. LARSEN-Stern and A. AlbreKston (2004): Growth and yield of Hybrid Larch (Larix x eurolepis A. Henry) in Southern Sweden. Scandinavian Journal of Forest Research 19: 320-328.

Einspahr, D. W., G. W. WyCOFF and M. Fiscus (1984): Larch - A fast growing fiber source for the Lake States and the Northeast. Journal of Forestry 82(2): 104-106.

Eysteinsson, T. (1992): Accelerated breeding of larch. Ph.D. thesis, University of Maine, Orono, ME, USA. $226 \mathrm{p}$.

Eysteinsson, T., M. S. Greenwood and J. Weber (1993): Management of a prototype indoor orchard for accelerated breeding of larch. CFRU Research Bulletin 9, Maine Agricultural Experiment Station Miscellaneous Report 377. 18 pp.

Ferrand, J. C. and J. C. BAstien (1985): Bilan a 26 ans d'une plantation comparative de Melezes. Revue Forestière Française 37: 441-448.

Gerlinger, N., D. JAQUES, M. SCHWANnINGER, R. Wimmer and L. E. PÂQUes (2004): Heartwood extractives and lignin content of different larch species (Larix sp.) and relationships to brown-rot decay resistance. Trees 18: 230-236.

Harrison, W. M. and B. E. Borders (1996): Yield prediction and growth projection for site-prepared loblolly pine plantations in the Carolinas, Georgia, Alabama and Florida. PMRC Technical Report 1996-1, D.B. Warnell School of Forest Resources, University of Georgia, Athens, GA, USA.
Kellison, R. C. (2014): A New Model for Forest Sector Research and Development in the United States: Follow-up article for the U.S. Endowment for Forestry and Communities. The State and Future of U.S. Forestry and the Forest Industry Conference. May 29-30 th , 2013. Washington, DC. http://www.usendowment.org/images/Forest_ R_D_Final_1.29.14.pdf Accessed 2-19-15.

KRETSCHMANN, D. E. (2010): Mechanical properties of wood. In: Wood handbook - Wood as an engineering material. General Technical Report FPL-GTR190. Madison, WI: U.S. Department of Agriculture, Forest Service, Forest Products Laboratory. 508 p.

LANGNER, W. and V. Schneck (1998): Ein Beitrag zur Zuechtung von Hybridlaerchen (larix $\mathrm{x}$ eurolepis Henry). Das Langenzeitprogramm der Firma von Lochow-Petkus. J.D. Sauerlaenders Verlag, Frankfurt am Main, $159 \mathrm{p}$.

Li, R., A. Weiskittel, A. R. Dick, J. A. Kershaw and R. S. SEYMOUR (2012): Regional stem taper equation for eleven conifer species in the Acadian region of North America: development and assessment. North Journal of Applied Forestry 29: 5-13.

MAINE Forest SERvice (2014): Annual Report. http://www.maine.gov/dacf/mfs/publications/ annual_reports.html\#silvi.

PÂQUES, L. E. (2004): Roles of European and Japanese larch in the genetic control of growth, architecture and wood quality traits in interspecific hybrids (Larix x eurolepis Henry). Annals of Forest Science 61: 25-33.

PÂQUES, L. E. (1989): A critical review of larch hybridization and its incidence on breeding strategies. Annals of Forest Science 46: 146-153.

PÂQUES, L. E. (1992): Performance of vegetatively propagated Larix decidua, L. kaempferi and L. laricina. Annals of Forest Science 49: 63-74.

Peer, K. R. and M. S. Greenwood (2001): Maturation, topophysis and other factors in relation to rooting in Larix. Tree Physiology 21: 267-272.

PERRON, M. (2008): A strategy for the second breeding cycle of Larix $\mathrm{x}$ marschlinsii in Quebec, Canada including experiments to guide interspecific tree breeding programme. Silvae Genetica 57: 282-285.

Pizer, W., M. Adler, J. Aldy, D. Anthoff, M. CropPer, K. Gillingham, M. Greenstone, B. Murray, R. Newell, R. Richels, A. Powell, S. Waldhoff and J. WIENER (2014): Using and improving the social cost of carbon. Science 346: 1189-1190.

SANDER, H. and A. LAANELAID (2007): The Dunkeld larch (Larix x marschlinsii Coaz) in Estonia. Dendrobiology 57: 73-80.

WESTERN WOOD PRODUCTS Association (2002): http://www.wwpa.org/SPECIESPRODUCTS/DouglasFir/tabid/405/Default.aspx

Herausgeber: Johann Heinrich von Thünen-Institut. Bundesforschungsinstitut für Ländliche Räume, Wald und Fischerei. Schriftleitung: Institut für Forstgenetik, Sieker Landstrasse 2, D-22927 Grosshansdorf Verlag: J. D. Sauerländer's Verlag, Berliner Strasse 46, D-63619 Bad Orb Anzeigenverwaltung: J. D. Sauerländer's Verlag, Bad Orb

Gesamtherstellung: PPPP Norbert Wege e.K., Gladenbach — Printed in Germany. 